\title{
Sprawozdanie
}

\section{Międzynarodowa Konferencja Naukowa Prawa człowieka - wspótczesne zjawiska, wyzwania, zagrożenia, Sosnowiec, 25 kwietnia 2014 r.}

W dniu 25 kwietnia 2014 r. w Wyższej Szkole „Humanitas” w Sosnowcu odbyła się międzynarodowa konferencja naukowa pt. „Prawa człowieka współczesne zjawiska, wyzwania, zagrożenia”. Organizatorami konferencji byli: Instytut Prawa i Administracji WSH wraz z Kołem Naukowym Studentów Prawa WSH „Prawo w praktyce”.

Patronat honorowy sprawowali: rzecznik praw obywatelskich prof. dr hab. Irena Lipowicz oraz komendant Szkoły Policji w Katowicach inspektor Jarosław Kaleta. Patronat naukowy objął prezes Oddziału Polskiej Akademii Nauk (PAN) w Katowicach prof. dr hab. Jerzy Klamka. Patronat medialny natomiast przypadł: „Nowej Politologii”, „Wiadomościom Zagłębia” oraz portalowi e-Sosnowiec. Sponsorem przerwy kawowej została firma Japan Motors Katowice.

Cel konferencji stanowiło zaprezentowanie, analiza, refleksja i dyskusja dotycząca zjawisk, wyzwań i zagrożeń z zakresu praw człowieka w kontekście m.in.: prawa prywatnego i publicznego, globalizacji, integracji europejskiej, zmian społecznych i kulturowych, a zwłaszcza zagrożeń dla bezpieczeństwa publicznego. Nieplanowanym pierwotnie, choć niezwykle istotnym zagadnieniem stał się kontekst naruszania praw człowieka podczas ukraińskiej rewolucji polityczno-społecznej zwanej potocznie „Euromajdanem". 
Powitania uczestników dokonali kolejno: prof. WSH dr Bolesław Ćwiertniak, dyrektor IAiP oraz J.M. rektor WSH prof. WSH dr Jerzy Kopel oraz dr Joanna Naczyńska - Dziekan Wydziału Administracji i Zarządzania WSH. Głos zabrał także przedstawiciel podmiotu sprawującego patronat naukowy nad konferencją - dyrektor Zakładu Działalności Pomocniczej Oddziału PAN w Katowicach mgr Stefan Gajda. Słowo wstępne wygłosiła także dr Anna Kalisz, opiekun Koła Naukowego Studentów Prawa WSH. Symbolicznego uroczystego otwarcia konferencji dokonała pomysłodawczyni oraz spiritus movens całego przedsięwzięcia - Viktoria Sadova, studentka prawa WSH.

Sesja plenarna pt. „Prawa człowieka - koncepcje i znaczenie” moderowana przez prof. dr. hab. Andrzeja Bisztygę (Górnośląska Wyższa Szkoła Handlowa w Katowicach) zawierała następujące referaty: 1) Wystąpienie polskich i ukraińskich studentów prawa (Victoria Sadova, Viktor Sadovy oraz Yuliia Labych) dotyczące naruszenia praw i wolności człowieka w trakcie pokojowych protestów podczas „Euromajdanu”; 2) prof. dr. hab. Dariusza Szostka (Uniwersytet Opolski) pt. „Naruszenie praw człowieka w Internecie”. W referacie tym poruszono kwestię dwojakiej roli Internetu w kontekście praw człowieka: jako medium pomagające w ich realizacji i ochronie poprzez kontrolę społeczną oraz jako narzędzie dla ich naruszeń. Ciekawą puentę stanowiła próba refleksji nad rozwojem technologicznym, za którego przykład posłużyły Google Glass - „okulary do podglądania - z wbudowaną kamerą, mikrofonem i GPS-em; 3) dr. Artura Biłgorajskiego (Uniwersytet Śląski) pt. „Granice wolności czy wolność ponad granicami? Kilka uwag na temat koncepcji wolności jednostki w Konstytucji RP w kontekście wolności wypowiedzi”. Wystąpienie dotyczyło samego pojęcia wolności jako dobra społecznego i prawnego, które de facto służy przede wszystkim tzw. „Zwykłym ludziom”. Państwo (prawodawca) wolności nie daje, jedynie ją chroni bądź ogranicza. W przypadku ograniczenia muszą spełnione zostać konkretne warunki wynikające z istoty państwa prawa. Problem rodzi zwłaszcza wyjątkowo konfliktogenna wolność wypowiedzi, wchodząca w kolizję z innymi prawami i wolnościami (przede wszystkim prawem do prywatności).

W tej sesji głos zabrali również: 1) dr Bogusław Przywora (Uniwersytet Jagielloński, GWSH) z referatem pt. „Trybunał Konstytucyjny jako organ kontroli celów i działalności partii politycznych - stan obecny i postulaty 
zmian”. Referat dotyczył interesującej - choć dość niszowej - kwestii roli TK jako „kontrolera” celów i działalności partii politycznych jako podmiotów wywierających niekwestionowany wpływ na państwo, społeczeństwo oraz jednostki; 2) dr Aleksandra Wentkowska (Pełnomocnik Terenowy Rzecznika Praw Obywatelskich, WSH), która przestawiła referat pt. „Rola RPO w ochronie praw człowieka”. Prezentacja dotyczyła kompetencji (ze szczególnym uwzględnieniem tego, co nie należy do gestii RPO), organizacji, struktury oraz procedur działalności RPO. Poruszane były praktyczne aspekty działalności, a sam referat ubarwiony był interesującymi przykładami z pracy Pełnomocnika Terenowego RPO, a także 3) dr Dorota Fleszer (WSH) z wystąpieniem pt. „Prywatność jako dobro osobiste człowieka”. Wystąpienie to rozpoczęła polemika $z$ tendencją do postrzegania prawa do prywatności jako kategorii „rozmytej” i opartej na rozumieniu na nieostrej, intuicyjnej i subiektywnie odczuwalnej definicji terminu „prywatność”. Prelegentka zaznaczyła, iż w dobie społeczeństwa informacyjnego oraz rozwoju technologii informacyjnych znaczenie prawa do prywatności wzrasta.

Sesję plenarną zakończyła dyskusja zdominowana przez prof. dr. hab. Andrzeja Bisztygę oraz dr Aleksandrę Wentkowską i zagadnienie relacji RPO jako „ombudsmana generalnego” z organami pełniącymi rolę „ombudsmanów wyspecjalizowanych”.

Po przerwie obiadowej obrady kontynuowano aż w sześciu równoległych sekcjach panelowych. W pierwszej sesji panelowej pt. „Prawa człowieka w ujęciu klasycznym”, moderowanej przez dr Joannę Naczyńską (SSO w Gliwicach, WSH) udział wzięli: 1) dr Urszula Dziki (WSH) z referatem „Prawo człowieka do środowiska naturalnego - wybrane aspekty prawne i pozaprawne”; 2) mgr Renata Płaszowska (UJ) z referatem „Legalne problemy związane $\mathrm{z}$ realizacją prawa dostępu do dziedzictwa ludzkości”; 3) mgr Adam Płoszka (Uniwersytet Warszawski) z referatem „Osoba bezdomna w perspektywie praw człowieka”; 4) mgr Michał Korszun (Uniwersytet Śląski) z referatem „Rozwój praw człowieka w kontekście współczesnych oczekiwań społecznych i możliwości ich realizacji przez państwo”; 5) Monika Wojtyczka (UŚ) z referatem „Swoboda wypowiedzi komercyjnej (reklamowej) i jej granice”; 6) Paulina Buczek i Paweł Mróz (UŚ) z koreferatem „Wolność prasy a prawo do prywatności osób prowadzących działalność publiczną". 
Druga sesja pt. „Prawa i wolności człowieka w aspekcie europejskim i międzynarodowym”, moderowana przez dr Annę Kalisz (WSH), zawierała wystąpienia: 1) doc. dr. Bogdana Nowosada (PWSZ Oświęcim) pt. „Prawa unijnego pasażera jako element praw człowieka trzeciej generacji”; 2) dr Renaty Jankowskiej (UŚ) pt. „Problem naruszeń praw człowieka na Cyprze w kontekście obecnej sytuacji politycznej”; 3) dr Kamili Kasperskiej-Kurzawy (Uniwersytet Opolski) pt. „Przestrzeganie praw człowieka na przykładzie Pakistanu i Afganistanu”; 4) mgr Katarzyny Cichos (UŚ) pt. „Prawo do rozwoju czy zobowiązanie do eliminacji ubóstwa?”; 5) Paulina Stawicka (Uniwersytet Mikołaja Kopernika w Toruniu) pt. „Przystąpienie UE do EKPC korzyści, zagrożenia i wyzwania”.

Sesję trzecią pt. „Prawa i wolności człowieka w świetle prawa konstytucyjnego i publicznego" moderował dr Maciej Borski (WSH). Udział w niej wzięli: 1) mgr Daniel Wojtczak (UŚ) z referatem „Zasada społeczeństwa obywatelskiego w orzecznictwie TK”; 2) Justyna Dzierżawska (UŚ) z referatem „Realizacja konstytucyjnego prawa do nauki na poziomie szkoły podstawowej”; 3) Michalina Nawrot (US) z referatem „Konstytucyjna wolność zgromadzeń. Zarys teorii i praktyki”; 4) Bartłomiej Samek (UŚ) z referatem „Konstytucyjne prawo do obrony jako gwarancja poszanowania praw człowieka w procesie karnym”; 5) Kamil Ciołek (US) - z referatem „Konstytucyjna zasada domniemania niewinności. Zarys teorii i praktyki” oraz 5) Karolina Wenecka (US) z referatem „Konstytucyjna zasada określoności prawa karnego (nullum crimen et nulla poena sine lege). Zarys teorii i praktyki”.

Czwarta sesja pt. „Prawa człowieka i ich ograniczenia w kontekście bezpieczeństwa”, której moderatorką była dr Magdalena Półtorak (WSH), składała się z następujących wystąpień: 1) prof. dr hab. Zygmunt Woźniczka (WSH) - „Konteksty historyczne naruszania praw człowieka w XX wieku”; 2) dr Tomasz Miłkowski (Szkoła Policji w Katowicach, WSH) - „Korzystanie przez służby policyjne z uprawnień do pozyskiwania informacji - spór przed Trybunałem Konstytucyjnym”; oraz 3) mgr Piotr Mączyński (UJ) - „Działania na rzecz bezpieczeństwa lokalnego jako czynnik kształtujący prawo do bezpieczeństwa osobistego".

W piątej sesji pt. „Prawa człowieka w prawie prywatnym oraz prawa człowieka w Internecie", moderowanej przez dr Annę Rogacką (WSH), udział wzięli: 1) mgr Magdalena Filipek-Marzec (Instytut Metali Nieżelaznych 
w Gliwicach) z referatem „Wywłaszczenie czy nacjonalizacja praw majątkowych w prawie autorskim?”; 2) Marcin Chowaniec (US) z referatem „Dobra osobiste lekarza"; 3) Zuzanna Kubica i Sandra Lubartowicz (US) z koreferatem „Naruszenie dóbr osobistych a tajemnica korespondencji”; 4) mgr Anita Strzebińczyk (UŚ) z referatem „Naruszenie dóbr osobistych w Internecie”; 5) mgr Joanna Przyjemska (Instytut Nauk Prawnych PAN) z referatem „Prawo dostępu do Internetu jako prawo człowieka”; 6) Łukasz Dziura (UJ) z referatem „Bastion wolności czy dzika dżungla? Analiza i próba odpowiedzi, czy Internet powinno się prawnie uregulować” oraz 7) Katarzyna Darowska i Joanna Lewandowska (US) z koreferatem „Ochrona dóbr osobistych w Internecie ze szczególnym uwzględnieniem portali społecznościowych”.

Ostatnia z sesji panelowych, szósta sesja pt. „Prawa człowieka w ujęciu prawa pracy”, której moderatorem był prof. dr Bolesław Ćwiertniak, zawierała następujące wystąpienia: 1) dr Paweł Czarnecki (Uniwersytet Kardynała Stefana Wyszyńskiego w Warszawie) - „Obowiązek wypłaty pieniężnego odszkodowania jako sankcja za naruszenie prawa socjalnego”; 2) dr Dariusz Makowski (Uniwersytet Łódzki) - „Państwowa Inspekcji Pracy jako organ ochrony praw pracownika”; 3) dr Anna Reda-Ciszewska (UKSW) - „Prawo do rokowań zbiorowych w administracji publicznej/służbie publicznej”; 4) dr Żaneta Grygiel-Kaleta (UJ) - „Ograniczenie wolności zrzeszania się w związki zawodowe”; 5) dr Janusz Żołyński (WSAiE Polkowice, KGHM) „Ograniczenia prawa do strajku”; 6) mgr Karolina Szymorek (UŁ) - „Prawo pracownika do prywatności w kontekście nowych możliwości technicznych kontroli pracowników".

Każdą z sesji zamykała dyskusja dotycząca poruszanych w niej tematów.

Konferencję zakończył tzw. round table prowadzony w języku rosyjskim przez dr Annę Kalisz, z udziałem pracowników IAiP oraz gości Koła Naukowego - studentów z Ukrainy.

Łącznie na konferencji zaprezentowano około 40 referatów pracowników naukowych, doktorantów i studentów z całej Polski oraz z Ukrainy.

Anna Kalisz

Wyższa Szkoła „Humanitas” w Sosnowcu 